\title{
Separation of Glutamate Dehydrogenases of Coprinus cinereus on Polyacrylamide Gels
}

\author{
By M. O. FAWOLE* \\ Department of Botany, Science Laboratories, University of Durham, \\ Durham DH I $_{3} L E$
}

(Received I March 1976; revised 28 July 1976)

INTRODUCTION

It is now well established that two forms of glutamate dehydrogenase (GDH) exist in fungi (Holzer \& Schneider, 1957; Sanwal, 1961; Sanwal \& Lata, 1961; Kato et al., 1962; Dennen \& Niederpruem, 1965; Fawole \& Casselton, 1972; Hynes, 1974) and in bacteria (LeJohn \& McCrea, 1968; Kramer, 1970; Brown, Macdonald-Brown \& Meers, 1974). Studies on fungal GDH have recently been reviewed by Brown et al. (1974). In some of these, two distinct enzyme proteins were separated. One form is linked to nicotinamide adenine dinucleotide (NAD-GDH; EC. I.4.I.2) and the other to nicotinamide adenine dinucleotide phosphate (NADP-GDH; EC. I.4. I.4).

The present study was designed to separate the two glutamate dehydrogenases of Coprinus cinereus using polyacrylamide gel electrophoresis.

\section{METHODS}

Organism and growth of cultures. The wild-type monokaryon, H9, of Coprinus cinereus (previously called C. lagopus) was grown as described by Fawole \& Casselton (1972), using ammonium medium with $\mathrm{I} \%(\mathrm{w} / \mathrm{v})$ sucrose instead of $2 \%(\mathrm{w} / \mathrm{v})$ glucose, and vigorously aerating the cultures in the dark at $25{ }^{\circ} \mathrm{C}$. Although glucose is better than sucrose as a carbon source for Coprinus (e.g. Moore, 1969), it strongly repressed NAD-GDH activity in the fungus (Fawole \& Casselton, I972; Stewart \& Moore, 1974), and so sucrose was used to minimize this effect.

Preparation of cell-free extracts. Mycelial pellets were collected by filtration through four layers of muslin and washed with water. In a preliminary experiment it was found that there was a substantial loss of GDH activity in mycelia stored at $-20{ }^{\circ} \mathrm{C}$ even for one week. Therefore, fresh mycelia were used in subsequent experiments. Mycelium was homogenized at full speed for two 90 s periods using a Virtis $\mathrm{S} 45$ homogenizer (Techmation, Edgware, Middlesex HA8 8JP) cooled in ice. The extractant was as used by Fawole \& Casselton (1972). The crude extract was centrifuged at $30000 \mathrm{~g}$ for $20 \mathrm{~min}$ at $2{ }^{\circ} \mathrm{C}$. The clear supernatant was dialysed for about $16 \mathrm{~h}$ at $2{ }^{\circ} \mathrm{C}$ against three changes of the extractant: before use, the dialysis tubing had been boiled for $20 \mathrm{~min}$ in $10 \%(\mathrm{w} / \mathrm{v})$ sodium carbonate and then rinsed in tap water followed by distilled water (Smith, 1968).

Enzyme assays. GDH was assayed at room temperature by measuring the oxidation of either NADH or NADPH at $340 \mathrm{~nm}$ in a Gilford 2000 automatic recording spectrophotometer using the reaction mixtures of Fawole \& Casselton (I972). Proteins were precipitated with $10 \%(\mathrm{w} / \mathrm{v})$ trichloroacetic acid (TCA), washed once with $5 \% \mathrm{TCA}$ and then twice

* Permanent address: Department of Botany, University of Ibadan, Ibadan, Nigeria. 
with ethanol. The precipitate was dissolved in $0 . \mathrm{I} \mathrm{M-NaOH}$ and the protein was determined by the method of Lowry et al. (195I), using bovine serum albumin as standard. Specific activities of GDH were expressed as nmol NADH or NADPH oxidized $\min ^{-1}$ (mg protein $)^{-1}$.

Polyacrylamide gel electrophoresis. This was carried out by the method of Davis (1964) with the following modifications. Experiments were done at room temperature, but the electrode solution container was immersed in a cold bath at $\circ$ to $4{ }^{\circ} \mathrm{C}$. The concentration of the main gel was reduced to $5 \%$ acrylamide plus $0.17 \%$ methylene bisacrylamide. The sample $(200 \mu \mathrm{g}$ in $0.2 \mathrm{ml})$ was mixed with $40 \%(\mathrm{w} / \mathrm{v})$ sucrose instead of using a sample gel, and then layered on the spacer gel. A constant current of $2 \mathrm{~mA}$ per gel was applied for the first $15 \mathrm{~min}$ and then increased to $5 \mathrm{~mA}$ per gel for $2 \mathrm{~h}$, during which time the reference bromophenol blue dye migrated to about $6 \mathrm{~mm}$ from the end of the gel. Gels were $75 \mathrm{~mm}$ long.

The gels were either stained for protein in $1 \%(\mathrm{w} / \mathrm{v})$ Coomassie brilliant blue in $7 \%(\mathrm{v} / \mathrm{v})$ acetic acid, or stained for GDH activity. In the latter case, gels were first extruded into cold $\mathrm{O} \cdot \mathrm{I} \mathrm{M}$-Tris/HCl buffer, $\mathrm{pH} 9.5$ for $30 \mathrm{~min}$, and then stained in a freshly prepared incubation mixture for $\mathrm{I} 5 \mathrm{~min}$ at $35^{\circ} \mathrm{C}$. The incubation mixture was modified from that of Laycock, Thurman \& Boulter (1965) and contained: $0.1 \mathrm{M}$-Tris/HCl buffer, $\mathrm{pH} \mathrm{9.5}$; sodium glutamate, $50 \mathrm{mg}$; $\mathrm{NAD}^{+}$or $\mathrm{NADP}^{+}$, $10 \mathrm{mg}$; $N$-methylphenazolium methosulphate, I mg; 3-(4,5-dimethylthiazol-2-yl)-2,5-diphenyltetrazolium bromide, $5 \mathrm{mg}$; in a total volume of io $\mathrm{ml}$.

Partial purification of enzymes. All operations for the partial purification of GDH were carried out at 0 to $4{ }^{\circ} \mathrm{C}$ (Table I). Solid $\left(\mathrm{NH}_{4}\right)_{2} \mathrm{SO}_{4}$ was added to the crude enzyme extract to $35 \%$ saturation. The precipitate which formed after 50 min stirring was removed by centrifuging and more solid $\left(\mathrm{NH}_{4}\right)_{2} \mathrm{SO}_{4}$ was added to the supernatant to $55 \%$ saturation. The resulting 35 to $55 \%\left(\mathrm{NH}_{4}\right)_{2} \mathrm{SO}_{4}$ protein fraction, after centrifuging, was redissolved in a minimum volume of extractant. It was then dialysed for $16 \mathrm{~h}$ against three changes of the extractant and treated with alumina Cy gel at $20 \mathrm{mg}$ gel (mg protein) ${ }^{-1}$ (Yamasaki \& Suzuki, 1969). The suspension was stirred for $15 \mathrm{~min}$, and the gel was recovered by centrifuging at $10000 \mathrm{~g}$ for $\mathrm{IO} \mathrm{min}$, and washed once with $0.05 \mathrm{M}$-phosphate buffer, $\mathrm{pH} 7.65$, plus I mM- $\beta$-mercaptoethanol. The enzyme was eluted from the gel by stirring for I $h$ with $5 \mathrm{ml} 0 . \mathrm{I} \mathrm{M}$-phosphate buffer, $\mathrm{pH} 7.65$, containing I mM- $\beta$-mercaptoethanol. After centrifuging the suspension at $20000 \mathrm{~g}$ for $15 \mathrm{~min}$, the supernatant was separated and the pellet was again stirred for two I $\mathrm{h}$ periods each with $5 \mathrm{ml} 0.2 \mathrm{M}$-phosphate buffer, $\mathrm{pH} 7.65$, containing I mM- $\beta$-mercaptoethanol, followed by centrifuging as before. The three eluates were pooled and then dialysed as above. Attempts to concentrate the enzyme using polyethylene glycol resulted in reduced enzyme activities, a result similar to that reported by Dennen \& Niederpruem (1967) using Schizophyllum commune.

\section{RESULTS AND DISCUSSION}

Most of the NAD-GDH and NADP-GDH activities of $C$. cinereus were found in the same 35 to $55 \%$ ammonium sulphate fraction (Table I). Both enzyme activities showed a single band after electrophoresis, the NADP-GDH band being more distinct than the NAD-GDH band. The difference in the intensities of the bands could be due to an instability of NAD-GDH under the conditions of electrophoresis, as has been observed in Neurospora crassa (Kapoor \& Grover, 1970). A faint band developed below the NADGDH band long after the normal incubation period and was greyish, in contrast to the normal purple GDH bands. When glutamate, NAD or NADP was omitted from the 
Table I. Summary of the procedure for the partial purification of $G D H$ from $C$. cinereus

Procedure

Crude undialysed extract

Crude dialysed extract

$\left(\mathrm{NH}_{4}\right)_{2} \mathrm{SO}_{4} 35$ to $55 \%$ saturation

Pooled alumina Cy eluates

\begin{tabular}{|c|c|c|c|c|}
\hline \multirow{2}{*}{$\begin{array}{l}\text { Total protein } \\
\text { (mg) }\end{array}$} & \multicolumn{2}{|c|}{ Specific activity } & \multicolumn{2}{|c|}{ Recovery of activity $(\%)$} \\
\hline & NAD-GDH & NADP-GDH & NAD-GDH & NADP-GDH \\
\hline 250 & 0.425 & 0.224 & 100 & 100 \\
\hline 216 & 0.496 & 0.247 & IOI & $95 \cdot 2$ \\
\hline 20 & $2 \cdot 877$ & 0.502 & $54 \cdot 2$ & $17 \cdot 9$ \\
\hline 4.4 & $4 \cdot 286$ & 0.539 & $17 \cdot 8$ & $4 \cdot 2$ \\
\hline
\end{tabular}

incubation mixture, no band appeared on the gel. The two stained enzyme bands coincided with two bands observed when gels were stained with Coomassie brilliant blue. The electrophoretic study of the partially purified enzymes confirms the existence of two distinct enzyme proteins. An indication of high molecular weights for the two enzymes was observed when the concentration of acrylamide was increased from 5 to $7 \%$, but with the same $0.17 \%$ methylene bisacrylamide. After $2 \mathrm{~h}$ in $7 \%$ acrylamide, NAD-GDH migrated only I mm and NADP-GDH only $\mathrm{I} \cdot 6 \mathrm{~mm}$ from the top of the running gel. However, after $2 \mathrm{~h}$ in $5 \%$ acrylamide, NAD-GDH and NADP-GDH migrated $18 \mathrm{~mm}$ and $34 \mathrm{~mm}$ respectively. Although no attempt has been made to estimate the molecular weight of GDH in C. cinereus, the enzyme is known to be a large molecule in $N$. crassa (Blumenthal \& Smith, 1973), bacteria (Yarrison, Young \& Choules, 1972), animals (Cassman \& Schachman, I97I) and higher plants (Chou \& Splittstoesser, I972).

I thank the Association of Commonwealth Universities for the award of an Academic Staff Fellowship to undertake this study. I also gratefully acknowledge the advice of Professor D. Boulter on this work and his criticism of the manuscript.

\section{REFERENCES}

Blumenthal, K. M. \& SMith, E. L. (1973). Nicotinamide adenine dinucleotide phosphate-specific glutamate dehydrogenase of Neurospora. I. Isolation, subunits, amino acid composition, -SH groups and identification of a lysine residue reactive with pyridoxal phosphate and $\mathrm{N}$-ethylmaleimide. Journal of Biological Chemistry 248, 6002--6008.

Brown, C. M., Macdonald-Brown, D. S. \& Meers, J. L. (1974). Physiological aspects of microbial inorganic nitrogen metabolism. Advances in Microbial Physiology, II I-52.

Cassman, M. \& SCHACHMan, H. K. (197I). Sedimentation equilibrium studies on glutamic dehydrogenase. Biochemistry, New York Io, IOI 5-1024.

Chou, K. \& SPlitTSTOesSER, W. E. (1972). Glutamate dehydrogenase from Pumpkin cotyledons. Characterization and isoenzymes. Plant Physiology 49, 550-554.

Davis, B. J. (1964). Disc electrophoresis. II. Method and application to human serum proteins. Annals of the New York Academy of Sciences I2I, 404-427.

DenNen, D. W. \& Niederpruem, D. J. (I965). Control of glutamate dehydrogenases in the basidiomycete Schizophyllum commune. Life Sciences 4, 93-98.

DENNEN, D. W. \& NiEderPRUEM, D. J. (1967). Regulation of glutamate dehydrogenases during morphogenesis of Schizophyllum commune. Journal of Bacteriology 93, 904-9I3.

Fawole, M. O. \& Casselton, P. J. (1972). Observations on the regulation of glutamate dehydrogenase activity in Coprinus lagopus. Journal of Experimental Botany 23, 530-551.

Holzer, H. \& SchneIDER, S. (1957). Anreicherung und Trennung einer DPN-spezifischen und einer TPNspezifischen Glutaminsäuredehydrogenase aus Hefe. Biochemische Zeitschrift 329, 36I-369.

Hynes, M. J. (1974). The effects of the carbon source on glutamate dehydrogenase activities in Aspergillus nidulans. Journal of General Microbiology 81, I65-1 70.

KapoOR, M. \& Grover, A. K. (I970). Catabolite-controlled regulation of glutamate dehydrogenases of Neurospora crassa. Canadian Journal of Microbiology r6, 33-40. 
Kato, K., KoIKe, S., Yamada, K., Yamada, H. \& Tankaka, S. (I962). Di- and triphosphopyridine nucleotide-linked glutamic dehydrogenases of Piricularia oryzae and their behaviours in glutamate media. Archives of Biochemistry and Biophysics 98, 346-347.

KRAMER, J. (1970). NAD and NADP-dependent glutamate dehydrogenase in Hydrogenomonas H 6 . Archiv für Mikrobiologie 7r, 226-234.

Laycock, M. V., Thurman, D. A. \& Boulter, D. (1965). An improved method for the detection of dehydrogenases using tetrazolium salts. Clinica chimica acta $\mathbf{I r}, 98$.

LEJoHN, H. B. \& MCCREA, B. (1968). Evidence for two species of glutamate dehydrogenases in Thiobacillus novellus. Journal of Bacteriology 95, 87-94.

Lowry, O. H., Rosebrough, N. J., FARr, A. L. \& Randall, R. J. (I95I). Protein measurement with the Folin phenol reagent. Journal of Biological Chemistry 193, 265-275.

Moore, D. (1969). Sources of carbon and energy used by Coprinus lagopus sensu Buller. Journal of General Microbiology 58, 49-56.

Sanwal, B. D. (I96I). Diphosphopyridine nucleotide and triphosphopyridine nucleotide linked glutamic dehydrogenases of Fusarium. Archives of Biochemistry and Biophysics 93, 377-386.

SANwal, B. D. \& LATA, M. (196I). The occurrence of two different glutamic dehydrogenases in Neurospora. Canadian Journal of Microbiology 7, 319-328.

Sмiтн, I. (I968). Chromatographic and Electrophoretic Techniques, vol. II, Zone Electrophoresis. London: Pitman Press.

STEWART, G. R. \& MoORE, D. (I974). The activities of glutamate dehydrogenases during mycelial growth and sporophore development in Coprinus lagopus (sensu Lewis). Journal of General Microbiology 83, 73-81.

YAMASAKI, K. \& SUZUKI, Y. (I969). Some properties of glutamate dehydrogenase from pea seedlings. Phytochemistry 8, 963-969.

YarRison, G., YounG, D. W. \& Choules, G. L. (1972). Glutamate dehydrogenases from Mycoplasma laidlawii. Journal of Bacteriology 110, 494-503. 